\title{
Assessment of the Adoption of Organic and Conventional Farming Methods in Kisii Central Sub-County, Western Kenya
}

\author{
Nyamwamu, N. Charles ${ }^{1, a^{*}}$, Onkundi, B. Elizabeth ${ }^{2, b}$ \\ ${ }^{1}$ Department of Agriculture, Mawego Technical Training Institute, P. O. Box 289 Oyugis, Kenya. \\ ${ }^{2}$ Department of Agricultural Education and Extension, Egerton University, P. O. Box 536, Njoro. \\ ${ }^{a *}$ Email: nyamwamucharles@gmail.com; Cellphone: +254725566033 \\ bEmail: elizaonkundi94@gmail.com; Cellphone; + 254712609354
}

${ }^{*}$ Corresponding Author

Keywords: Slurry, Mulch, Composting, Organic, Kisii

\begin{abstract}
This study sought to determine the extent of adoption of various organic and conventional crop and soil management practices in the farms. Ten farms were sampled at an equidistance of one kilometre along a transect laid across each of the eight randomly selected sublocations in the sub county. A sample size of 80 farms was randomly selected from the Sub-County. The eighty farms were regrouped into two; Organic and conventional farms. A survey of the crop management practises was carried out and the observed methods recorded down. The data collected was analyzed using the Statistical paired t test and descriptive statistics. Use of pesticides recorded the highest percentages $(60 \%)$ in conventional methods while mulching recorded relatively high percentage (42\%) in organic methods. Use of plastic cover recorded the lowest percentage of $4 \%$ in conventional methods while vermi-composting was not embraced in conventional methods. Conventional methods were 3.33 points higher than organic $(95 \%$ CI [-9.37596, 16.04263]). Conventional and Organic farming methods were strongly and negatively correlated $(r=-0.069$, $p>0.05)$. However, there was no statistical significant difference between conventional and organic methods $\left(t_{5}=0.674, p>0.05\right)$, [Appendix 1(iii)]. The knowledge obtained will be useful to the farmers and other participants globally to improve crop productivity. The information collected will also enable farmers seek for unconventional ways to alleviate the problem of heavy usage of agrochemicals in order to embrace organic farming for the long run sustainability of the agricultural sector.
\end{abstract}

\subsection{Introduction}

Organic farming is a system of agricultural production without any use of agrochemicals with an environmentally and socially responsible approach [5]. This farming practice occur at grass-roots level, which restores soil fertility [8]. According to $[5,6,28]$ conventional farming systems employ use of agro-chemical inputs and lead into reduction of soil productivity and negatively affect environmental services.

The undesirable consequences of higher use of agrochemicals are decrease in crop yield and drop in the quality of natural resources. According to [22] the environment will be affected by carbon emission of the agricultural system through direct use of fossil fuel in farm operations, indirect use of embodied energy for producing agricultural inputs and depletion of humus during tilling of soils. Similarly [10] had also affirmed that intensive agriculture and excessive use of agrochemicals have resulted into degradation of soil, water and genetic resources and in turn, negatively effecting crop yields.

Intensive cultivation coupled with usage of agrochemicals negatively affects environmental resources. According to [23] based on the long term agrarian studies and experiments conducted in EU and North America have asserted that significant amount of organic matter have been depleted due to intensive tillage of land. Globally, farmers need to look for alternative ways to alleviate the problem of heavy usage of agrochemicals and finally arrive at organic farming as the only solution 
of the problem and also for the long run of the sustainability of the agricultural sector as observed by $[13,15]$.

Various agricultural practices have the potential to reduce the emission of greenhouse gasses by appropriate crop management agronomic practices [13]. The scholars further observed that nitrogen application rates in organic farming are 62-70 per cent lower than conventional agriculture due to recycling of organic crop reduce and use of manure. Similarly, [19] have also pointed out that greenhouse gasses emissions from organic farming are 36 per cent lower than conventional system of crop production.

[20] had reported that the organic farming system has the potential of reducing irrigation water and sequestration of $\mathrm{CO}_{2}$. Efficient and effective use of inputs and net income per unit of cultivated crops on organic farms are at par due to reduction in costs of farm inputs [21]. [7]) have pointed out that the humus improves soil structure, enhances water-holding capacity of soil and protects soil against erosion. In regard to this, [20] have observed that organic farming has the capability to increase the sequestration rate on arable land and in combination with no tillage system of crop farming, this can be easily increased by three to six quintal carbon per hectare per year.

Soil erosion, depletion of humus, mono-cropping and poor utilization of artificial fertilizers are the major reasons for soil fertility depletion in arable farms [24, 25]. Organic farmers make use of natural pest controls such as biological control cause pest resistance and often pollute water and land [5]. According to $[1,16,17]$, reduction in the use of toxic synthetic pesticides, which poison an estimated three million people each year, should lead to improved health of farm families.

[3] affirmed that transition to organic production and increasing urge for organic products attracts premium prices for the certified organic farmer, this will prompt the conventional farmers to consider going to organic way of crop, pest and soil management practices. In a study conducted by [11], observed that organic farming practices, is an alternative option for promoting crop production in most countries in Africa. Their findings further highlighted the need of inspiring resourceconstrained farmers to adopt organic farming methods; these practices allow farmers to lower production overheads; are environmental friendly and thus increase crop productivity. Therefore, this study sought to determine the extent of adoption of various organic and conventional crop and soil management practices on the farms in Kisii central Sub county and the information collected will also enable farmers seek for unconventional ways to alleviate the problem of heavy usage of agrochemicals in order to embrace organic farming for the long run sustainability of the agricultural sector.

\subsection{Materials and Methods}

\subsection{Description of the study area}

Kisii Central Sub County is one the nine Sub Counties of Kisii County, Western Kenya. It has six locations with seventeen sub-locations (Source: County commissioner office, Kisii County, 2015). Temperature ranges from $10^{\circ} \mathrm{C}$ to $30^{\circ} \mathrm{C}$. The Sub County (formerly Kisii Central district) had a population of 588,000 . However, with a population growth rate of $3.6 \%$ the population is now over 700,000 (19\% of whom live in urban areas [12]. It is one of the most highly populated Sub Counties in Kenya and covers an area of $317.4 \mathrm{~km}^{2}$. Due to the high population pressure, considerable portion of the land is converted for other purposes beside agricultural activities. The available land is partitioned among families; farm size is small with an average farm being $15,000 \mathrm{~m}^{2}[14,16]$. With an average of a quarter of an acre allocated for arable farming, almost all farmers engage largely in home-based agricultural production and minimal production for sale. The area allocated for cash crop farming is approximately 3,800ha while for food crop production is about 12,500ha [17]. Livestock farming is predominated by dairy and local poultry keeping. Agriculture offers employment for an estimated $80 \%$ of the inhabitants either directly or indirectly and the estimated rural poverty is $30 \%$ with some areas with $61 \%$ based on the Kisii county profile [17]. 


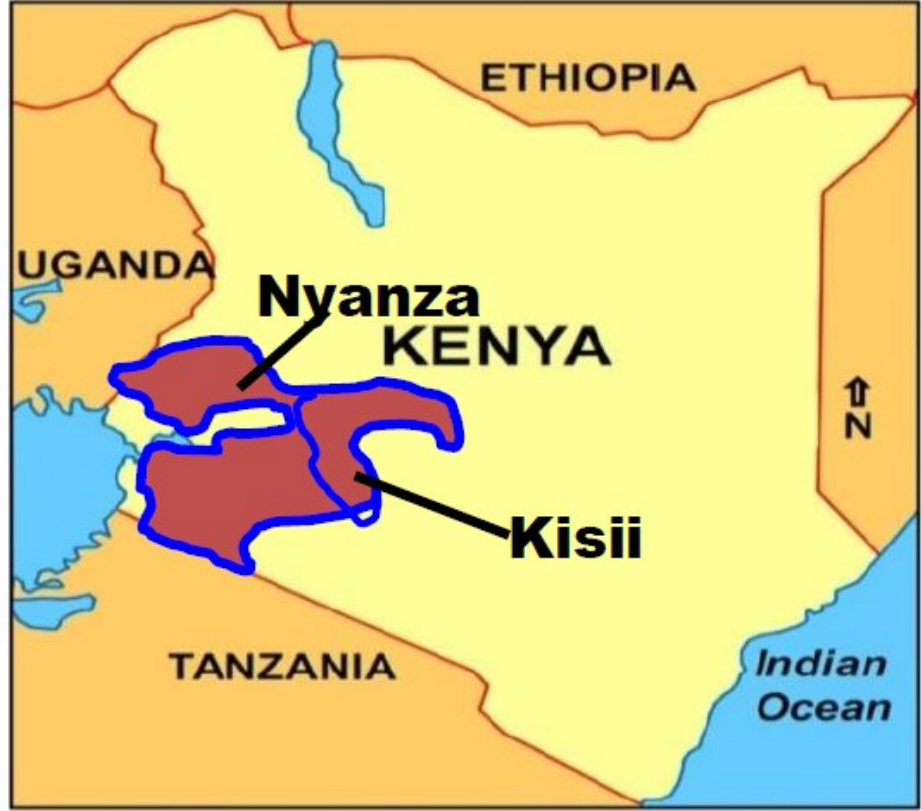

Figure 1: Kisii County, Nyanza Province of Kenya, where the research was undertaken. Source: Kisii County profile plan (25/6/2020)

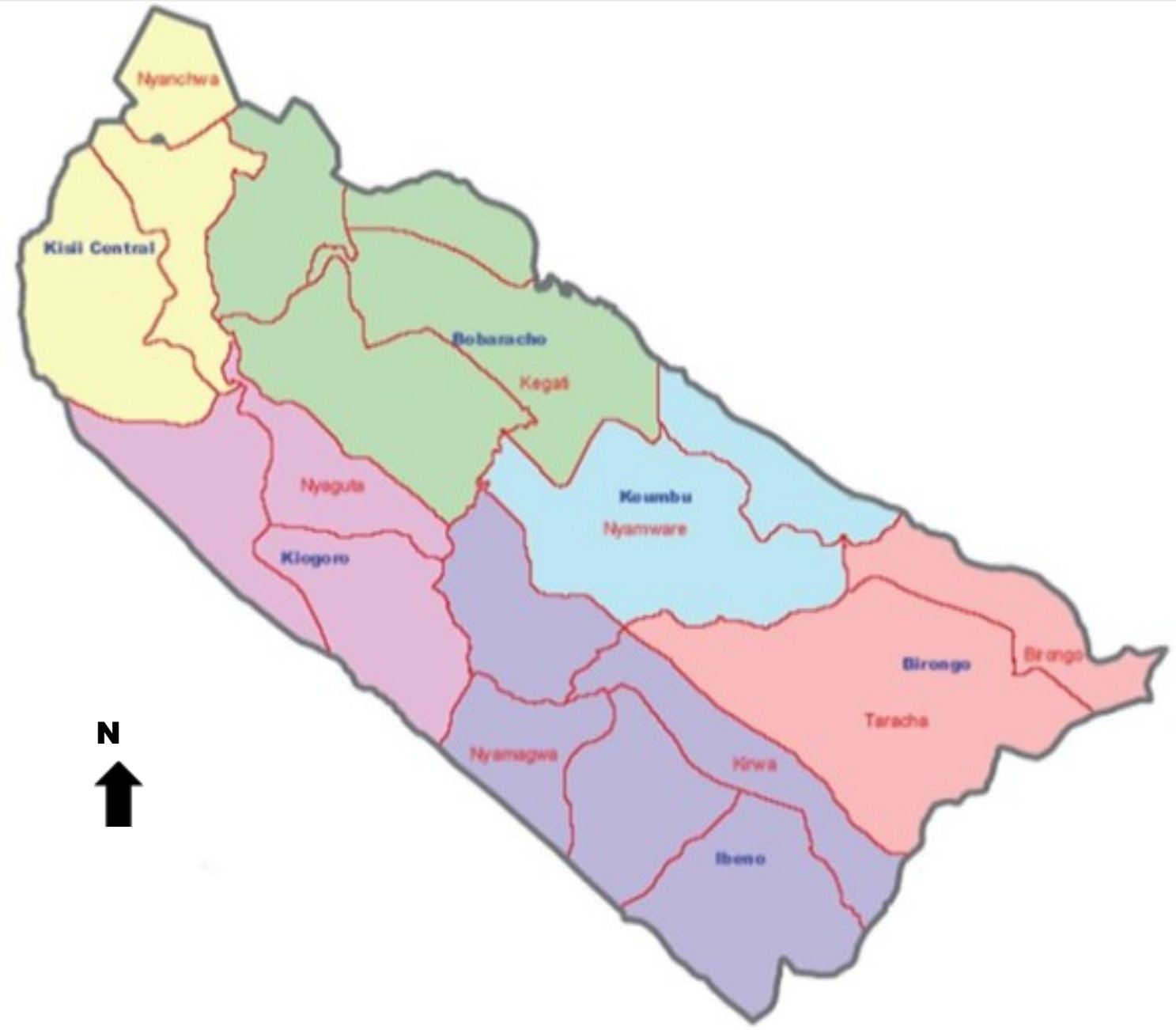

Figure 2: Kisii Central Sub-County Regions in Kisii County where the research was done. Source: Kisii County profile plan (25/6/2020) 


\subsection{Sample Size and Sampling Procedures}

The seventeen sub-locations in Kisii Central Sub County were labeled separately on same size pieces of paper, folded and placed in a common pool. An individual was asked to pick only eight, randomly one after the other to represent the six locations. From each of the eight randomly sampled sub-locations, ten farms were then selected at equidistant along transect dropped along the sub-location to give a total sample size of eighty (80) farms which were used for this study.

\subsection{Data collection}

A survey in the eighty farms was done in order to observe farming methods employed. The farms were then categorised into two main groups; those that embraced organic farming and the other farms that employed the conventional farming methods. However, this study considered six organic means of soil and crop production; mulching, compost-shed, pesticides, bio-slurry, vermicomposting and plastic cover.

\subsection{Data Analysis}

Data on organic and conventional crop and soil management methods was analysed using descriptive statistics. Mean differences and correlation was computed using paired-sample t-test.

\subsection{Results}

\subsection{Organic and conventional crop management methods}

This study considered six organic methods of soil conservation and crop production; mulching, compost-shed, pesticides, bio-slurry, vermi-composting and plastic cover. A survey was done in each farm to record the number and compute the percentage of farms with various crop and soil management practices as illustrated in Table 1.

Table 1: Organic and conventional crop management methods.

\begin{tabular}{l|l|l|l|l}
\hline \multirow{2}{*}{ Practice } & \multicolumn{4}{c}{ No. of Farms } \\
\cline { 2 - 5 } & Conventional & Organic & \multicolumn{2}{c}{$\begin{array}{l}\text { Percentage } \\
(\%)\end{array}$} \\
\hline & Number & $\begin{array}{l}\text { Percentage } \\
(\%)\end{array}$ & Number & 26 \\
Compost shed & 6 & 12 & 8 & 6 \\
Pesticides & 30 & 60 & 2 & 42 \\
Mulch & 9 & 18 & 12 & 10 \\
Plastic cover & 2 & 4 & 3 & 13 \\
Bio slurry & 3 & 6 & 4 & 3 \\
Vermi-composting & 0 & 0 & 1 & $\mathbf{1 0 0}$ \\
\hline TOTAL & $\mathbf{5 0}$ & $\mathbf{1 0 0}$ & $\mathbf{3 0}$ & \\
\hline
\end{tabular}

Figure 3.1 shows the percentage of organic crop and soil management methods recorded in the surveyed farms. Mulching had the highest percentage of $42 \%$ followed by compost shed at $26 \%$ while vermi- composting had least percentage at $3 \%$. 


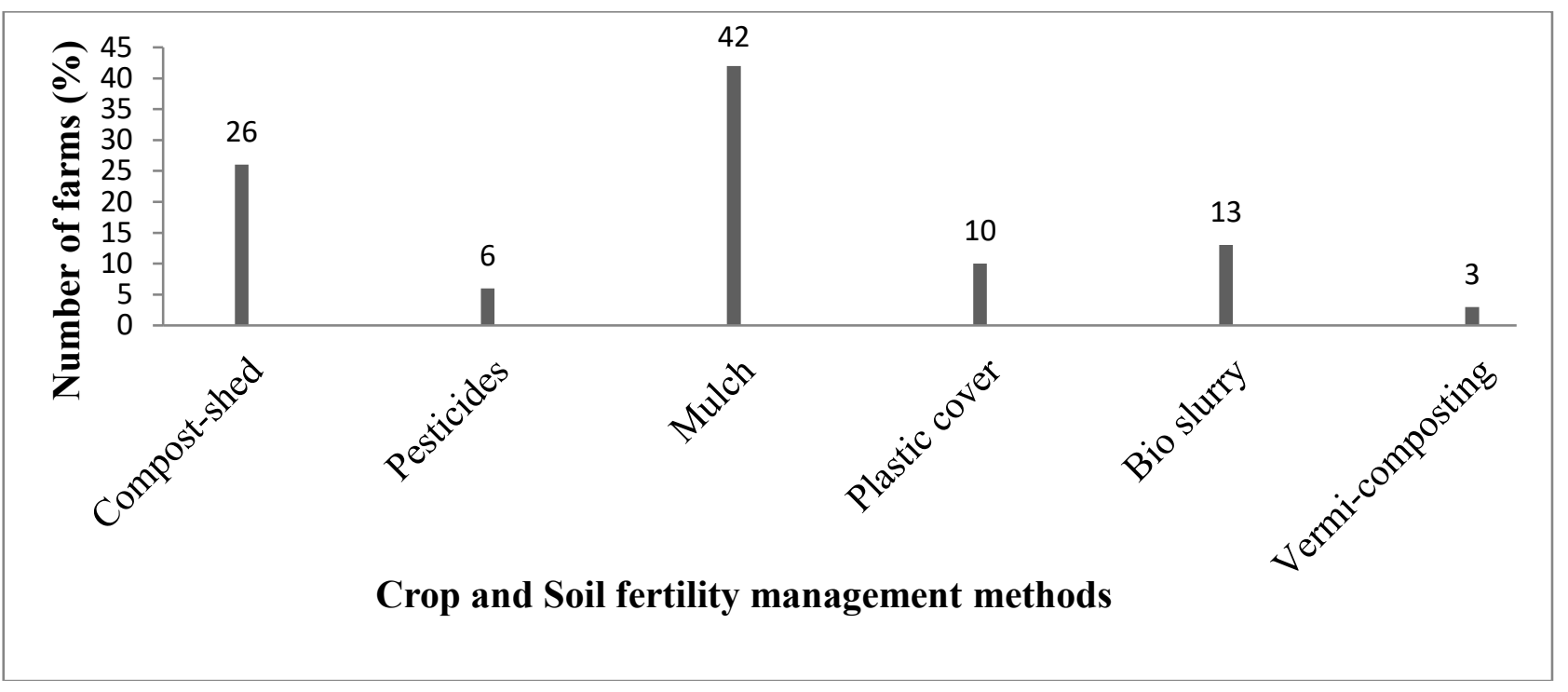

Figure 3.1: Organic crop and soil management methods.

Figure 3.2 shows the percentage of conventional crop and soil management methods recorded in the surveyed farms. Use of pesticides recorded the highest percentage $(60 \%)$ followed by mulching at $18 \%$ while composting, bio slurry, plastic cover and vermi-composting recorded percentages of 12, 6, 4 and 0 respectively.

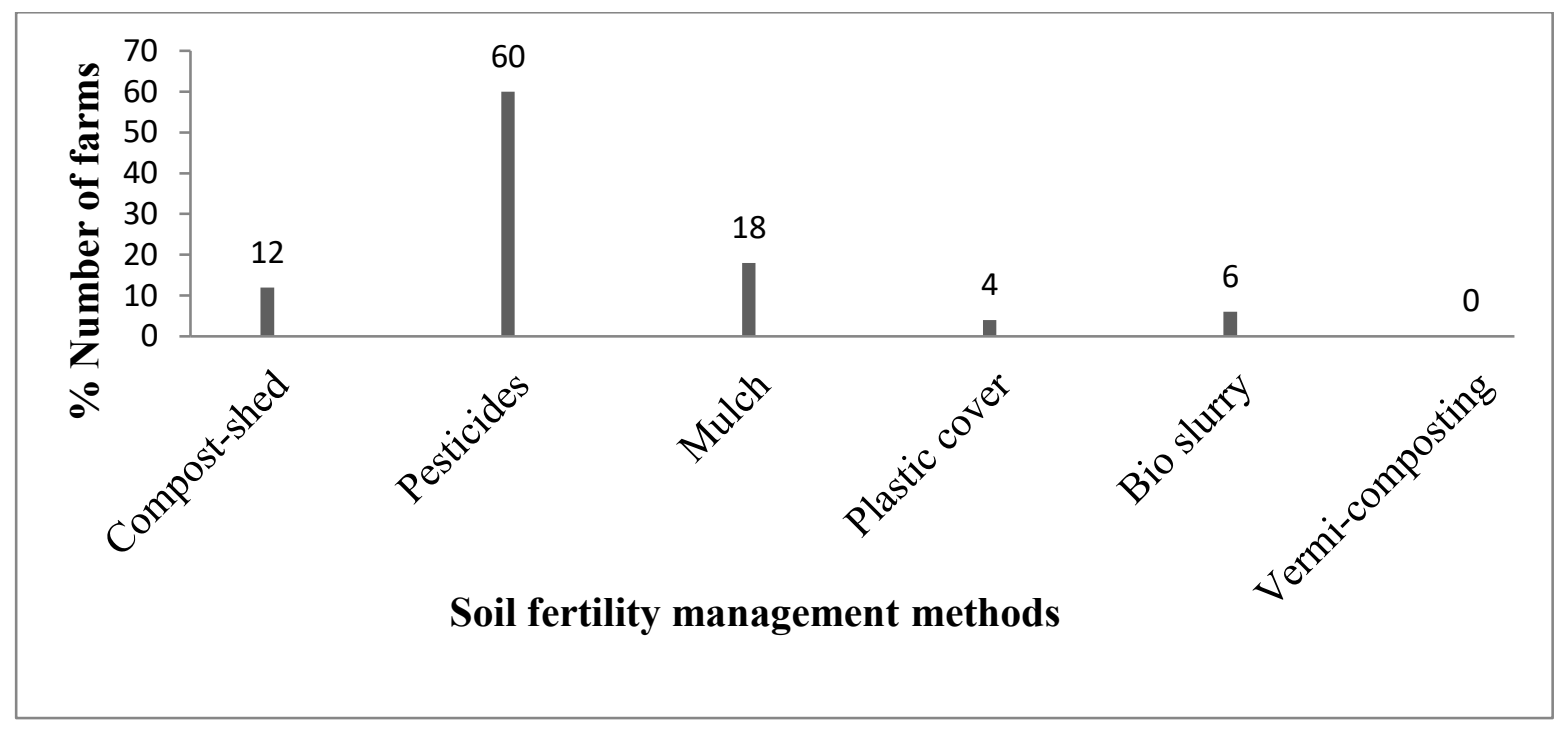

Figure 3.2: Conventional crop and soil fertility management methods.

Comparison of the percentages of organic and conventional crop management methods recorded in the surveyed farms was done. Use of pesticides recorded the highest percentages $(60 \%)$ conventional crop management methods while mulching recorded relatively high percentage (42\%) in organic methods. The use of plastic cover recorded the lowest percentage of $4 \%$ in conventional crop management practices while vermi-composting was not embraced in conventional crop management methods as illustrated in Figure 3.3. 


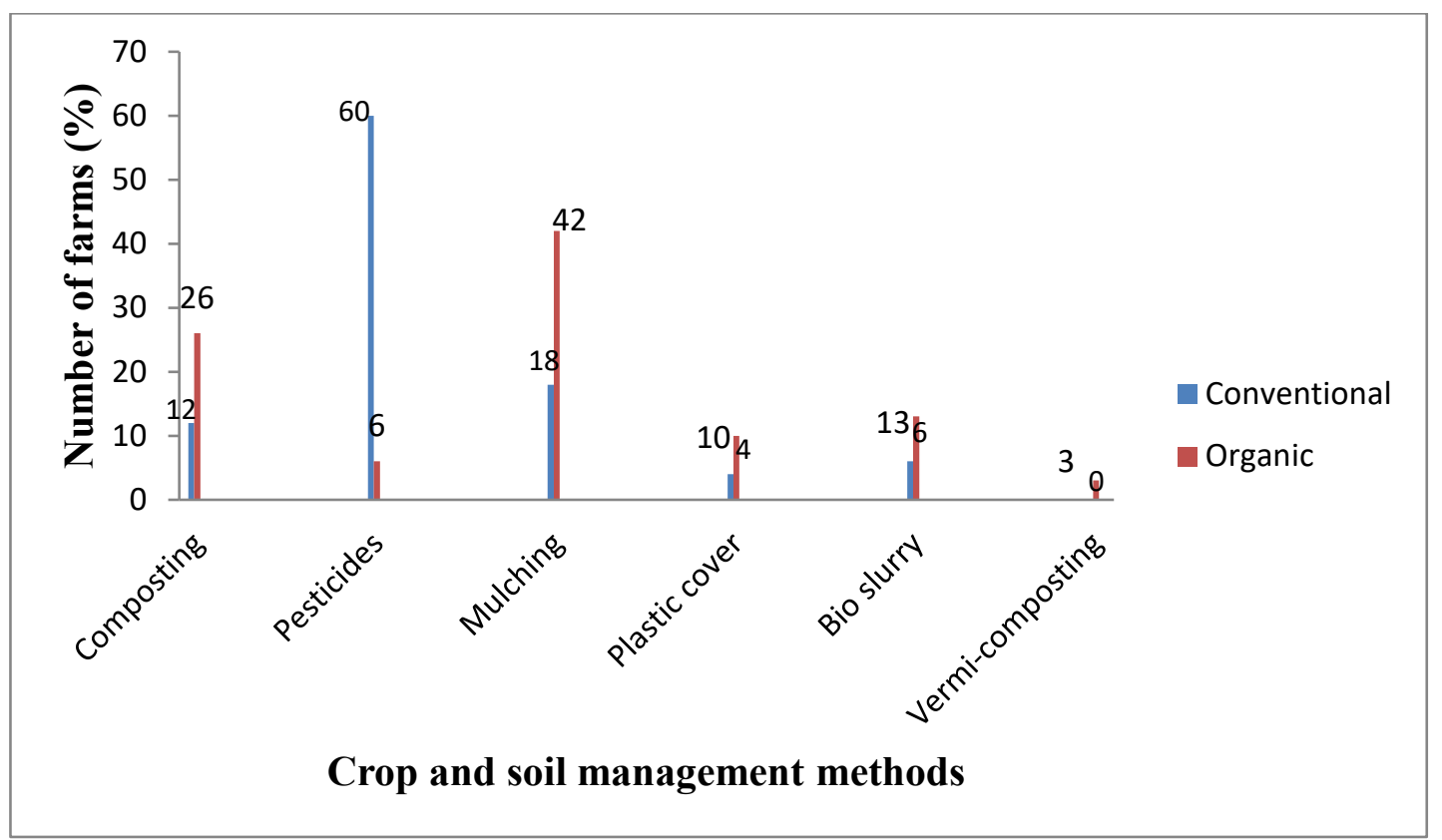

Figure 3.3: Organic and conventional crop and soil management practices

\subsection{Discussions}

This study considered six organic methods of crop management practices; mulching, compost-shed, bio-pesticides, bio-slurry, vermi-compost and plastic cover. Mulching involves covering soil surface around the plants in order to prevent soil moisture loss, protect plant roots, decrease weed regeneration and improve soil productivity [9]. Conventional soil and crop management methods were highly embraced as compared to organic crop management measures. It was observed that few farmers are either applying compost manure or mulching as crop management practices. Composting involves mixing of organic residues such as manures, plant material and any other biodegradable material. It provides vital quantities of crop residues to crops, enhances soil structure and its water retention ability [2].

This study considered compost-shed as an alternative for farm yard manure since it reserves the manure heap from sun volatilization effects or water percolation and thus upholds its nutrient availability to crops [2]. The study further revealed that few farmers do apply bio-pesticides to the crops for pest control. Conventional pesticides were commonly used by most farmers in control of crop pests. These pesticides end up into crop products used by humans. Few farmers embraced biopesticides which control pests via non-toxic ways and thus have no harmful effect on soil unlike the conventional pesticides [4].

Bio-slurry, is a by-product obtained from biogas plant after digestion of dung or other biomasses for the generation of methane gas. Though it was observed in a few farms, it has a potential to refresh soil productiveness as observed by [27].

This study considered biogas as a substitution to farms applied with bio-slurry. Bio-slurry discharged from the digester-system possesses much of the nutrients initially found in the feeding material. This in turn makes bio-slurry effective organic manure [26]. Effective application of the bio slurry has been proven to increase crop produce than regular manure. It also offers an appropriate remedy to nutrient exhaustion of most arable soils.

Plastic cover utilizes a plastic-clad semi-circular structure to cover soil around the root zone near crops. According to [18], bio slurry enhances crop production and increases soil quality by improving soil moisture and access of minerals to crops. Therefore, farmers should be advised not to rely entirely on conventional methods of crop management since they have detrimental effects on crops and soil in the long run. 
Conventional and Organic methods were strongly and negatively correlated $(r=-0.069$, $\mathrm{p}>0.05)$. However, there was no statistical significant difference between conventional and organic methods $\left(t_{5}=0.674, p>0.05\right)$. On average, conventional methods were 3.33 points higher than organic (95\% CI [-9.37596, 16.04263]) [Appendix: 1(iii)].

\subsection{Conclusion}

There was a significant average disparity between conventional and organic methods and therefore, farmers in Kisii central sub county rely heavily in conventional soil and crop management methods. Availability of modern artificial inputs like chemical fertilizers, pesticides and micronutrients in the farmers' disposal, conventional farmers still integrate organic methods of soil and crop management practices which includes mulching, compost-shed, bio-slurry, biopesticides and plastic cover and vermi-compost.

However, the adoption level for those methods is low among organic farmers in the study area, which implies that organic farmers are less informed on taking up various sustainable soil fertility and crop management methods. Most farmers supplement most of crop management practices. Though such rare methods like plastic cover, vermi-compost, bio-slurry and bio-pesticides are employed, they are not maximally utilized.

\section{Conflict of interest}

"The author(s) declare(s) that there is no conflict of interest."

There was no role of the funding sponsors in the design of the study; in the collection, analyses or interpretation of data; in the writing of the manuscript, or in the decision to publish the results.

\section{Acknowledgement}

The author would like to acknowledge the input and support offered by Ministry of Agriculture, Kisii Central sub-county and all the farmers of the surveyed farms.

\section{Appendix 1: Data Analysis Outputs}

(i) Paired Samples Statistics

\begin{tabular}{|c|c|c|c|c|c|}
\hline & & Mean & $\mathrm{N}$ & Std. Deviation & Std. Error Mean \\
\hline \multirow{2}{*}{ Pair 1} & $\mathrm{CONV}$ & 8.3333 & 6 & 11.07550 & 4.52155 \\
\hline & ORGANIC & 5.0000 & 6 & 4.19524 & 1.71270 \\
\hline
\end{tabular}

(i) Paired Samples Correlations

\begin{tabular}{|ll|r|r|r|}
\hline & \multicolumn{1}{|c|}{$\mathrm{N}$} & Correlation & \multicolumn{1}{c|}{ Sig. } \\
\hline Pair 1 & $\begin{array}{l}\text { CONV \& } \\
\text { ORGANIC }\end{array}$ & & -.069 & .897 \\
\hline
\end{tabular}

(iii) Paired differences

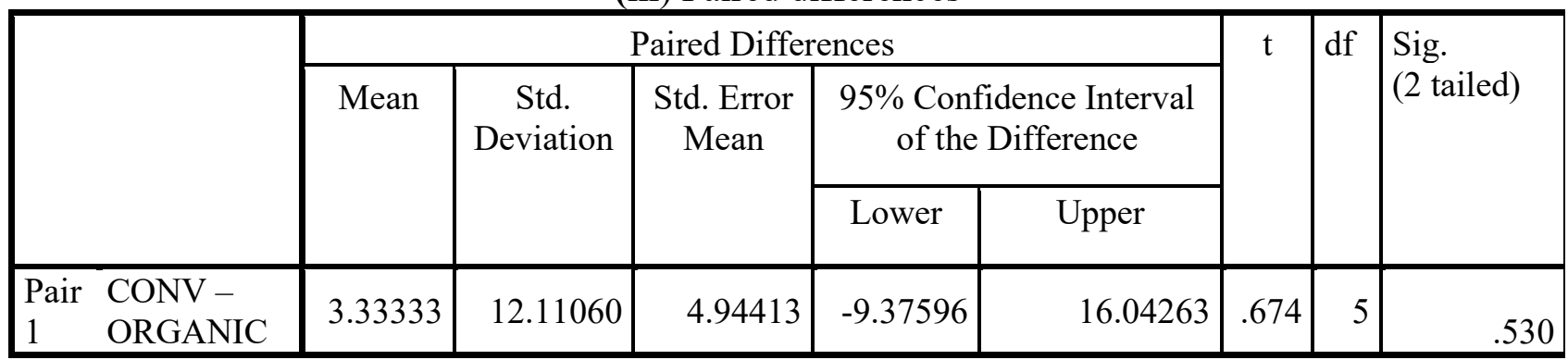




\section{References}

[1] Bhatta, G.D. \& Doppler, W. 2014. Socio-economic and environmental aspects of farming practices in the peri-urban hinterlands of Nepal. The Journal of Environment and Agriculture, 11, 26-39.

[2] Bista, P., Ghimire, R., Shah, C.S. \& Pande, K.R. 2013 Assessment of soil fertility management practices and their constraints in different geographic locations of Nepal. Forum Geografic, 9, 41-48.

[3] Delate, K. and Cynthia, A. 2003. "Organic Production Works", Online, Institute of Science in Society, available on the world wide web: http://lists.ifas.ufl.edu/cgi-bin/wa.exe?A2= ind $0412 \& \mathrm{~L}=$ sanet 13

[4] EPA 2013. Biopesticides. Washington D.C.: United States Environmental Protection Agency (US-EPA)

[5] FAO 2014. Organic Agriculture: FAQ. Retrieved on July 5, 2014 from http://www.fao.org: http://www.fao.org/organicag/oa-faq/oa-faq5/en/

[6] FAO (2010). Agricultural extension services delivery system in Africa: Food and Agriculture Organization, of the United Nations

[7] FiBL \& IFOAM. 2015. The world of organic agriculture: Statistics and emerging trends. Frick and Bonn: Research Institute of Organic Agriculture (FiBL) and International Federation of Organic Agriculture Movements (IFOAM).

[8] FiBL \& IFOAM. 2014. The world of organic agriculture: Statistics and emerging trends. Frick and Bonn: Research Institute of Organic Agriculture (FiBL) and International Federation of Organic Agriculture Movements (IFOAM).

[9] Jaleta, M., Kassie, M. \& Shiferaw, B. 2014. Tradeoffs in crop residue utilization in mixed crop-livestock systems and implications for conservation agriculture and sustainable land management. International Association of Agricultural Economists (IAAE) Triennial Conference, (pp. 18-24). Foz do Iguacu, Brazil.

[10] Joshi, P.K. 2015 “Conservation Agriculture: An Overview”, Indian Journal of Agricultural Economics, Vol. 66, No.1 pp.53-63.

[11] Kassie, Menale, Zikhali, Precious, Pender, John and Köhlin, Gunnar 2008. “Organic Farming Technologies and Agricultural Productivity: The case of Semi-Arid Ethiopia" Paper provided by Göteobrg University, Dept. of Economics in its series Working Papers in Economics with number 334, 2008, available on the world wide web: http://ideas.repec.org/p/hhs/ gunwpe/0334.html.

[12] KNBS (Kenya National Bureau of Statistics), 2009. Kenya population and Housing Census.

[13] Kramer, S.B., Reganold, J.B., Glover, J.D., Bohannan, B. J.M and Mooney, H.A. 2006. "Reduced Nitrate Leaching and Enhanced Denitrifier Activity and Efficiency in Organically Fertilised Soils" Proceedings of the National Academy of Sciences of the USA., Vol. 103, pp. $4522-4527$

[14] Ministry of Agriculture 2015. Community Empowerment on Farmer Organisation and Good Agricultural Practices. Kenya, Agricultural Information Centre

[15] Ministry of Agriculture 2014. Economic Review of Agriculture. Prepared by the Central Planning and Monitoring Unit. Nairobi: Ministry of Agriculture, Kenya.

[16] MoA (Ministry of Agriculture), 2016. Farm Management Handbook of Kenya Vol. II Natural Conditions and Farm Management Information. 2nd Edition, Part a West Kenya Subpart A2 Nyanza Province, MoA Kenya in Cooperation with GTZ. Ministry of Agriculture, Nairobi. 
[17] MoA (Ministry of Agriculture), (2012). Annual Work Plan: Kisii County. Ministry of Agriculture, Nairobi.

[18] Montri, A. \& Biernbaum, J. 2009. Management of the soil environment in high tunnels. Hort Technology, 19 (1), 34-36.

[19] Nemecek, T. Hugnenin, O., Elie, Dubois, D. and Gailord, G. 2005. "Okobilanzierung von, anbausystemen im schweizericschen Acker - und futterbau", Schriftenreihe der FAL, 58 FAL Reckenholz, Zurich.

[20] Niggli, U., Fliebach, A. Hepperly, P., Hanson, J. Douds, D. and Seidel, R. 2013. "Low Greenhouse Gas Agriculture: Mitigation and Adoption Potential of Sustainable Farming System", Food and Agriculture Organization, Review - 2, pp.1-22.

[21] Pimentel, D., Hepperly, P. Hanson, J., Douds, D. and Seidel, D. 2005. "Environmental, Energetic and Economic Comparisons of Organic and Conventional Farming Systems", Bioscience, Vol.55 pp.573-582.

[22] Pretty, Jules and Ball, A. 2014. Agricultural Influences on Carbon Emissions and Sequestration: A Review of Evidence and the emerging Trading Options, Occasional Paper, Centre for Environment and Society and Department of Biological Sciences, University of Essex, U.K.

[23] Robert, M., Antoine, J. and Nachtergaele, F. 2001. Carbon Sequestration in soil, Proposal for Land Management in Arid Areas of the Tropics, AGLL, Food and Agriculture Organization of the United Nations, Rome, Italy.

[24] Samie, A., Abedullah, A. M. \& Kouser, S. (2014). Economics of conventional and partial organic farming systems and implications for resource utilization in Punjab (Pakistan). Pakistan Economic and Social Review, 48 (2), 245-260.

[25] Shrestha, N., Raes, D. \& Sah, S.K. 2013. Strategies to improve cereal production in the Terai region (Nepal) during dry season: Simulations with aquacrop. Procedia Environmental Sciences, 19, 767-775.

[26] Warnars, P. 2016. From Biomass to Biogas: Present Day Status \& Future Requirements. Master Thesis - International Development Studies, Utrecht University, pp. 64.

[27] Warnars, L. 2015. Bioslurry: the new brown gold? Bioslurry manual. Hivos

[28] WFP. 2009. The Future of Food: Creating sustainable communities through climate adaptation. Retrieved1012, 2011, from http://reliefweb.int/sites/reliefweb.int/files/resources/ F1AA71E084C1D47B852576BD00634D1A-Full_Report.pdf. 